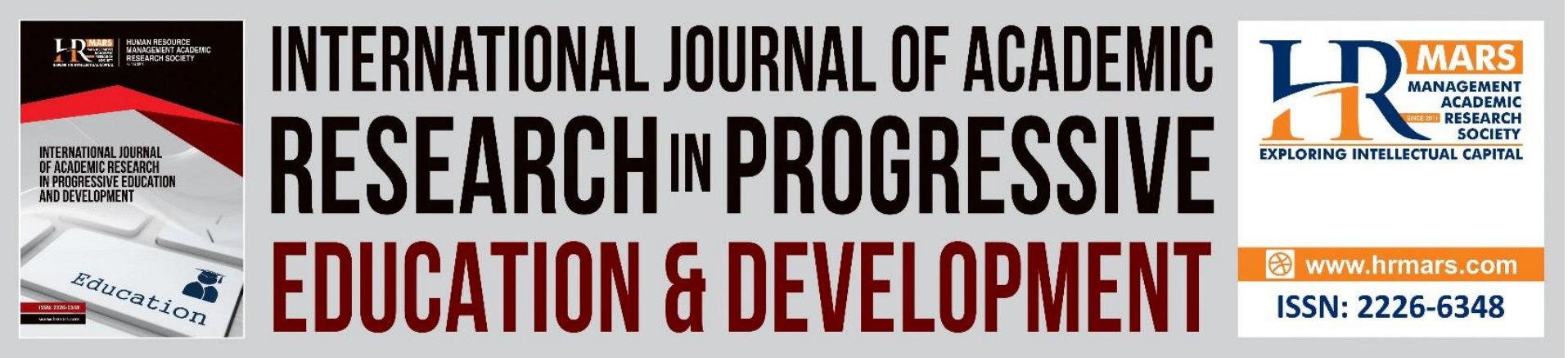

\title{
Professional and Technical Competencies Needed by Teachers of Business Studies in Junior Secondary Schools in Ondo State, Nigeria
}

Raymond Uwameiye, Ogunbamerun Mercy Titilayo

To Link this Article: http://dx.doi.org/10.6007/IJARPED/v1-i4/11968

DOI: $10.6007 /$ IJARPED/v1-i4/11968

Received: 19 October 2012, Revised: 20 November 2012, Accepted: 30 November 2012

Published Online: 29 December 2012

In-Text Citation: (Uwameiye \& Titilayo, 2012)

To Cite this Article: Uwameiye, R., \& Titilayo, O. M. (2012). Professional and Technical Competencies Needed by Teachers of Business Studies in Junior Secondary Schools in Ondo State, Nigeria. International Journal of Academic Research in Progressive Education and Development, 1(4), 61-70.

Copyright: (c) 2012 The Author(s)

Published by Human Resource Management Academic Research Society (www.hrmars.com)

This article is published under the Creative Commons Attribution (CC BY 4.0) license. Anyone may reproduce, distribute, translate and create derivative works of this article (for both commercial and non-commercial purposes), subject to full attribution to the original publication and authors. The full terms of this license may be seen at: http://creativecommons.org/licences/by/4.0/legalcode

\section{Vol. 1(4) 2012, Pg. 61 - 70}

Full Terms \& Conditions of access and use can be found at http://hrmars.com/index.php/pages/detail/publication-ethics 


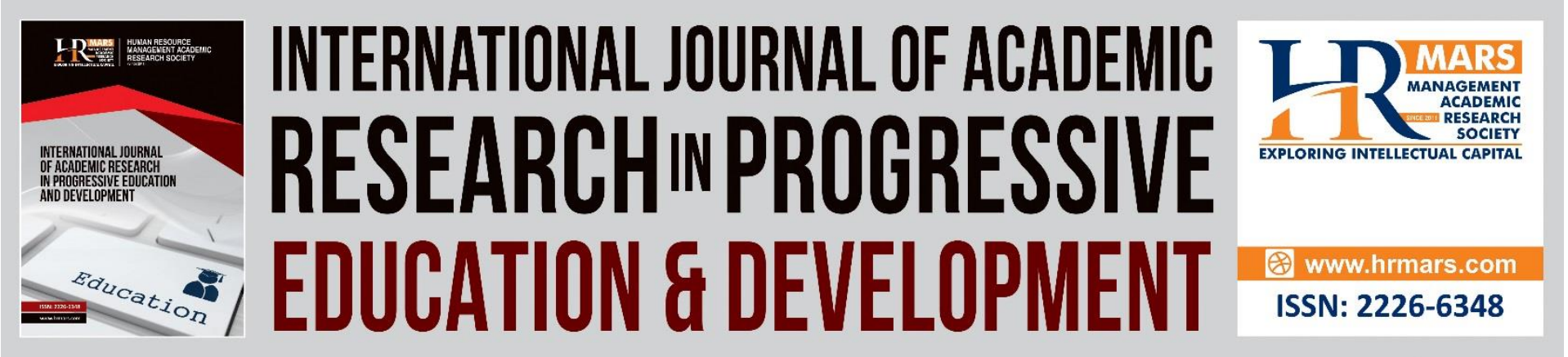

\title{
Professional and Technical Competencies Needed by Teachers of Business Studies in Junior Secondary Schools in Ondo State, Nigeria
}

\author{
Prof Raymond Uwameiye \\ Department of Vocational and Technical Education, Ambrose Alli University, Ekpoma Nigeria
}

\author{
Ogunbamerun Mercy Titilayo (Mrs) \\ Adeyemi College of Education, Ondo Nigeria
}

\begin{abstract}
This study investigated the professional and technical competencies needed by teachers of business studies in junior secondary school in Ondo State, Nigeria. A sample of 120 of professionally qualified teachers of business studies in Ondo state were randomly selected for the study. PTCCTBSQ which is a 45 item questionnaire developed by the researcher was the instrument used in this study. One of the findings of this study is that that teachers of Business Studies in Ondo State public Junior secondary schools need improvement in instructional planning, implementation and evaluation skills, as well as in core Business skills in relation to the teaching of office practice, shorthand and keyboarding as well as in commerce, bookkeeping and ICT. One of the recommendations of this study is that the identified tasks items where the teachers of Business Studies needed improvement be packaged for retraining of the in-service teachers of Business Studies in Ondo State junior secondary schools.
\end{abstract}

Keywords: Professional Competencies, Technical competencies, Business Studies

\section{Introduction}

Business is a productive activity which satisfies human needs. Awoyokun, AkangbeFolaranmi, Arukwe \& Abdullahi (2009) defined business as organized activities directed towards producing goods and services, in a profitable and consumer satisfying manner. In the context of this study, a business consists of organized productive activities which satisfy identified societal needs with or without profit motive. From the foregoing, Business Studies is a subject at the junior secondary school level in Nigeria in which business activities are organized for the purpose of learning.

According to Ehimetalor et al (2009), Business Studies consists of learning activities in relation to shorthand, commerce, keyboarding, office practice, book keeping and computer education. Business studies in the context of this study is a subject at the junior secondary school to enable them acquire basic skills in office practice, shorthand, commerce, bookkeeping, keyboard and computer education. 
The junior secondary school business studies curriculum of Federal Ministry of Education (2007) has the followings at its objective:

1. To provide basic business skills for person use now and in the future.

2. To prepare students for further training in business studies.

3. To relate the knowledge and skills to national economy.

4. To develop basic skills in office practice.

5. To provide the orientation and basic skills for with which to start an occupation for those who may not have the opportunity to further their training beyond junior secondary school.

Junior secondary school is the first stage of secondary education which has three years duration (Federal Government of Nigeria, 2004). It is the level of school where pupils who have completed six years of primary education are admitted to continue their last three years of secondary education.

Teaching in the view of Filani (2010) is a systematic process of imparting desirable knowledge, values, attitude and skills to the learner. Effective teaching is a systematic, rational and organized process of translating knowledge, skills, attitude and values in accordance with certain professional principles (Folarin, 2009). The teaching of Business Studies has not been without challenges.

Uwameiye and Osunde (2000) identified poor quality teacher who were ill equipped to teach prevocational subjects such as business studies as one of the major problems hindering the realization of prevocational education objectives in Nigeria. Adeniyi (2007) supported the view by stressing the need for adequate provision of human and material resources for effective teaching of Business Studies to promote saleable skill acquisition and possible employment generation. Also, an informal interaction with business studies teachers in junior secondary schools in Ondo State revealed that there are some professional and technical tasks that are challenging to the teachers in their teaching of Business Studies curriculum contents. Eze and Ag Somma (2005) stressed that there is a positive relationship between teacher perception of their self efficacy and job performance and that the understanding facilitates human accomplishment and personal well being. The authors of this study believe there is a level of motivation that will enable teachers with high assurance of their abilities to approach the challenge threats. This will help teachers maintain strong commitment to reaching their set goals and persevere with resilience in the face of difficult situations. And this will remove stress and depression, task avoidance and low self concept among in-service teachers as appropriate in-service training can be organized to improve the teachers' competence.

\section{Purpose of this Study}

The purpose of this study is to find out the professional and technical competencies which are challenge to teachers of Business Studies in teaching Business Studies to their students in junior secondary school in Ondo State. Specifically, this study sought to find out:

1. The instructional management tasks that are challenging to Business Studies teacher in which they require improvement in Ondo State, 
2. The tasks in teaching keyboarding, shorthand and office practice which are challenging to the business teachers in Ondo State,

3. The tasks in teaching bookkeeping, commerce and ICT which are challenging to teachers of Business Studies in which they require improvement in Ondo State.

\section{Research Questions}

The three research questions that guided this study included the following:

a. What are the general instructional management (planning, implementing and evaluating) tasks that are challenging to Business Studies teachers in which they require improvement in Ondo?

b. Which specific tasks are challenging to Business Studies teachers in teaching keyboarding, shorthand and office practice in which they require improvement in Ondo State?

c. Which specific tasks are challenging to Business Studies teachers in teaching Bookkeeping, commerce and ICT in which they require improvement in Ondo State?

\section{Method of the Study \\ Research Design}

This study adopted the descriptive survey research design. Olaitan, Ali, Eyo and Sowande (2000) reported that descriptive survey is used to study large or small population by selecting and analyzing data collected from respondents through the use of questionnaire. Descriptive Survey research is suitable for this study because the study obtained data from teachers of business studies in Ondo State public junior secondary schools through the use of questionnaire.

\section{Population for this Study}

The population for the study was 596 Business Studies teachers in 294 junior secondary schools in Ondo State.

\section{Sample and Sampling Technique}

Of the 596 Teachers of Business Studies in Ondo State, 120 of them professionally qualified were randomly selected through the balloting technique.

\section{Instrument for this Study}

The instrument for data collection for this study was a structured questionnaire named "Professional and Technical Competencies which are Challenges to Teachers of Business Studies Questionaire PTCCTBSQ". PTCCTBSQ is a 45 item questionnaire developed by the researcher. The source of PTCCTBSQ is the literature on this subject. The questionnaire was divided into two categories which are: the needed categories and the challenging categories. The scale for the needed category has a 4 point response options of highly needed $(H N)=4$, averagely needed $(A N)=3$, slightly needed $(S N)=2$ and Not Needed $(N N)=1$. The scale for the challenging categories also has a 4 point response options of Not Challenging $(N C)=4$, Slightly Challenging $(S C)=3$, Averagely Challenging $(A C)=2$ and Highly Challenging $(H C)=1$.

\section{Validity for this Study}

Three experts from the Department of Vocational Teacher Education (Business Education Unit) University of Nigeria face validated PTCCTBSQ. 
DEVELOPMENT

Vol. 1 , No. 4, 2012, E-ISSN: $2226-6348$ @ 2012 HRMARS

\section{Reliability for this Study}

A pilot group made up of 20 teachers of Business Studies from a neighboring state (outside the target population) was arranged for the reliability for this study. PTCCTBSQ was administered on the pilot group. After two weeks PTCCTBSQ was gain administered on the group. The data were collated and Pearson Product Moment Formula (PPMC) was used to analyze the data to obtain a coefficient of reliability of 0.76 .

\section{Administration of Questionnaire}

Five designated contact persons were trained as research assistants for this study. 120 copies of the questionnaire were administered on the respondents. The researcher and the research assistants went through all the schools to administer the questionnaire. Two weeks after the first administration, the researcher and the researcher assistants went through the schools to collect the questionnaire. Out of 120 copies that were given out to teachers, 115 copies (95.83\%) were returned and analyzed.

\section{Data Analysis}

Weighted mean was the main statistical tool used in this study. The difference between the two weighted means of needed and performance represent performance Gap for each item i.e. $P G=X N-X C H$. The decision rule was such that:

1. Where value of $P G$ is positive $(+)$ it means improvement is needed because the level at which the teachers were performing in teaching the item to students was lower than the level at which the item was needed;

2. Where the value of PG is negative (-) it means improvement is not needed because the level at which the teachers were performing (teachers needed capability) in teaching the item to students was higher than the level of challenge face by teachers in teaching the task; and

3. Where the value of PG is zero (0), it means that improvement is also not needed because teachers performance (capability) level in teaching the item to students was equal to the level of challenge been faced by teacher on the task.

\section{Findings}

The findings for this study were obtained from the analysis of the research questions answered and are presented in table 1-3

Research Question 1: What are the general instructional management (planning, implementing and evaluating) tasks that are challenging to Business Studies teachers in which they require improvement in Ondo? 
INTERNATIONAL JOURNAL OF ACADEMIC RESEARCH IN PROGRESSIVE EDUCATION AND DEVELOPMENT

Vol. 1, No. 4, 2012, E-ISSN: $2226-6348$ (C) 2012 HRMARS

Table 1: General Instructional Management Tasks that Pose challenges to Business Studies Teachers

\begin{tabular}{|c|c|c|c|c|c|}
\hline S/N & ITEM STATEMENT & $\mathbf{x}$ & $\mathbf{X P}$ & $X n-X P$ & REMARKS \\
\hline & $\begin{array}{l}\text { PLANNING INSTRUCTION } \\
\text { ABILITY TO: }\end{array}$ & & & & \\
\hline 1. & Select instructional content of a lesson & 3.91 & 3.63 & 0.28 & IN \\
\hline 2. & $\begin{array}{l}\text { Select available human and material } \\
\text { resources need for planning a lesson }\end{array}$ & 3.91 & 2.64 & 1.27 & IN \\
\hline 3. & Construct a lesson plan & 3.55 & 2.95 & 0.60 & IN \\
\hline 4. & $\begin{array}{l}\text { Select methods and techniques for teaching a } \\
\text { lesson }\end{array}$ & 3.85 & 2.71 & 1.14 & IN \\
\hline \multirow[t]{2}{*}{5.} & Select evaluation techniques & 3.97 & 3.90 & 0.07 & IN \\
\hline & $\begin{array}{l}\text { IMPLEMENTING INSTRUCTION } \\
\text { ABILITY TO: }\end{array}$ & & & & \\
\hline 6. & $\begin{array}{l}\text { Introduce a lesson to motivate students } \\
\text { interest and participation }\end{array}$ & 3.88 & 2.99 & 0.89 & IN \\
\hline 7. & Use various teaching strategies & 3.88 & 2.96 & 0.96 & IN \\
\hline 8. & Deliver the lesson in a logical order & 3.58 & 2.02 & 1.56 & IN \\
\hline 9. & $\begin{array}{l}\text { Utilize appropriate instructional materials } \\
\text { when teaching }\end{array}$ & 3.63 & 3.33 & 0.30 & IN \\
\hline 10. & $\begin{array}{l}\begin{array}{l}\text { Relate lesson to students daily life } \\
\text { experiences }\end{array} \\
\end{array}$ & 3.00 & 2.89 & 0.11 & IN \\
\hline \multirow[t]{2}{*}{11.} & $\begin{array}{l}\text { Provide a conducive classroom environment } \\
\text { for effective theoretical and practical work }\end{array}$ & 3.91 & 3.63 & 0.28 & IN \\
\hline & $\begin{array}{l}\text { EVALUATION INSTRUCTION } \\
\text { ABILITY TO: }\end{array}$ & & & & \\
\hline 12. & $\begin{array}{l}\text { Ascertain whether the objectives of a lesson is } \\
\text { achieved }\end{array}$ & 3.71 & 3.87 & -0.16 & INN \\
\hline 13. & $\begin{array}{l}\text { Construct valid and reliable tests to evaluate } \\
\text { students performance }\end{array}$ & 3.90 & 3.21 & 0.69 & IN \\
\hline 14. & Involve students in evaluating their progress & 3.92 & 2.55 & 1.37 & IN \\
\hline 15. & $\begin{array}{l}\text { Identify areas of students' weaknesses } \\
\text { through test instruments. }\end{array}$ & 3.88 & 2.13 & 1.75 & IN \\
\hline
\end{tabular}

KEY

IN $=$ Improvement Needed

INN $=$ Improved Not Needed

$\mathrm{Xn}=$ Mean of Needed Category

$\mathrm{Xp}=$ Mean of Performance Category

Table I reveals that performance gap values of the teachers on 14 out of 15 task items ranged from 0.07 to 1.75 and were positive. This indicates that the teacher needed improvement in the 14 items. The table also revealed that one of the items had a negative performance gap value of -0.16 . This indicated that the teacher did not need improvement on the item. Generally the result as contained in the table showed that the teachers of Business Studies in Junior Secondary Schools in Ondo State Needed Improvement in instructional skill areas. 
Research Question 2: Which specific tasks are challenging to Business Studies teachers in teaching keyboarding, shorthand and office practice in which they

Table 2: require improvement in Ondo State?

Performance Gap Analysis of Mean Rating Responses of Teachers of Business Studies in skills for teaching Office Practice, Keyboarding and Shorthand Tasks

\begin{tabular}{|c|c|c|c|c|c|}
\hline$S / N$ & ITEM STATEMENT & $\mathbf{X n}$ & Xp & $P G=X n-X p$ & REMARKS \\
\hline & $\begin{array}{l}\text { OFFICE PRACTICE } \\
\text { Ability to: }\end{array}$ & 3.91 & 3.63 & 0.28 & IN \\
\hline 16. & Use model office to teach office concepts & 3.89 & 2.68 & 1.21 & IN \\
\hline 17. & $\begin{array}{l}\text { Model office staff such as a receptionist, a } \\
\text { secretary, office manager, store keeper, } \\
\text { accountant at work. }\end{array}$ & 3.34 & 2.98 & 0.36 & IN \\
\hline 18. & $\begin{array}{l}\text { Role play employability skills such as } \\
\text { punctuality, loyalty courtesy, truthfulness, } \\
\text { corporate ethnics and culture i.e. dressing } \\
\text { code, telephone ethnics, customer } \\
\text { satisfaction. }\end{array}$ & 3.80 & 3.25 & 0.55 & IN \\
\hline 19. & $\begin{array}{l}\text { Demonstrate practical office procedures i.e. } \\
\text { preparation of store requisition, pay voucher, } \\
\text { receipt, pay roll and pay slip }\end{array}$ & 3.29 & 3.12 & 0.17 & IN \\
\hline \multirow[t]{2}{*}{20.} & $\begin{array}{l}\text { Use office machines, such as computer, } \\
\text { adding machine, photocopier, printer, } \\
\text { scanner etc }\end{array}$ & 3.52 & 3.23 & 0.29 & IN \\
\hline & SHORTHAND & & & & \\
\hline 21. & $\begin{array}{l}\text { Rule vertical and horizontal line on the } \\
\text { chalkboard }\end{array}$ & 3.68 & 2.48 & 1.20 & IN \\
\hline 22. & $\begin{array}{l}\text { Use arrows to show direction of writing } \\
\text { shorthand }\end{array}$ & 3.74 & 2.66 & 1.08 & IN \\
\hline 23. & Write shorthand outlines & 3.74 & 3.86 & -0.12 & INN \\
\hline 24. & Pronounce consonants in distinctive form & 3.98 & 2.04 & 1.94 & IN \\
\hline \multirow[t]{2}{*}{25.} & Prepare word passage & 3.99 & 3.79 & 0.20 & IN \\
\hline & KEYBOARDING & & & & \\
\hline 26. & Demonstrate correct sitting position & 3.52 & 3.63 & -0.11 & INN \\
\hline 27. & $\begin{array}{l}\text { Prepare charts on keyboard rows and correct } \\
\text { finger position }\end{array}$ & 3.75 & 2.48 & 1.27 & IN \\
\hline 28. & $\begin{array}{l}\text { Drill students on speed and accuracy at } \\
\text { various levels }\end{array}$ & 3.88 & 2.69 & 1.19 & IN \\
\hline 29. & $\begin{array}{l}\text { Demonstrate various types of paragraphs i.e. } \\
\text { blocked, indented and hanging }\end{array}$ & 3.82 & 3.45 & 0.37 & IN \\
\hline 30. & $\begin{array}{l}\text { Demonstrate various types of display i.e. } \\
\text { memo, notice, itineraries and single page }\end{array}$ & 3.73 & 3.64 & 0.09 & IN \\
\hline
\end{tabular}

Table 2 reveals that performance gap values of the respondents in thirteen (13) tasks clustered items - five (5) task items in office practice, five (5) in keyboarding and three (3) in shorthand had positive values which ranged from 0.17 to 1.27. This indicates that the 
INTERNATIONAL JOURNAL OF ACADEMIC RESEARCH IN PROGRESSIVE EDUCATION AND

DEVELOPMENT

Vol. 1, No. 4, 2012, E-ISSN: 2226-6348 @ 2012 HRMARS

teachers required improvement in those areas, while two (2) task clustered items, numbers 23 and 26 in table 2, listed under shorthand tasks cluster had negative values of -0.12 and 0.11 . This revealed that the teachers needed no improvement in those areas. Generally, the result reveals that teachers of Business Studies needed improvement in secretarial related tasks.

Research Question 3: Which specific tasks are challenging to Business Studies teachers in teaching Bookkeeping, commerce and ICT in which they require improvement in Ondo State?

Table 3:

Performance Gap Analysis of Mean Ratings of Responses of Teachers of Business Studies in Skills for Teaching Commerce, Bookkeeping and ICT Tasks

\begin{tabular}{|c|c|c|c|c|c|}
\hline$S / N$ & ITEM STATEMENT & $\mathrm{Xn}$ & $X p$ & $P G=X n-X p$ & REMARKS \\
\hline & COMMERCE & & & & \\
\hline 31 & Prepare chart on division of commerce & 3.90 & 3.64 & 0.26 & IN \\
\hline 32. & $\begin{array}{l}\text { Distinguishes various forms of business } \\
\text { organizations }\end{array}$ & 3.32 & 3.36 & -0.04 & INN \\
\hline 33. & $\begin{array}{l}\text { Visits production firms with students on } \\
\text { experimental learning of production and } \\
\text { occupational concepts - i.e. forms of } \\
\text { production, factors of production, type of } \\
\text { occupations }\end{array}$ & 3.81 & 3.50 & 0.31 & IN \\
\hline 34. & $\begin{array}{l}\text { Demonstrate the use of modern } \\
\text { communication and transportation gadgets }\end{array}$ & 3.62 & 3.50 & 0.12 & IN \\
\hline \multirow[t]{2}{*}{35.} & $\begin{array}{l}\text { Role play commercial workers to demonstrate } \\
\text { values such as honesty, hardworking, } \\
\text { customer protection etc. }\end{array}$ & 3.65 & 3.29 & 0.36 & IN \\
\hline & SHORTHAND & & & & \\
\hline 36. & $\begin{array}{l}\text { Extract information from various source } \\
\text { documents into the journal }\end{array}$ & 3.64 & 3.40 & 0.24 & IN \\
\hline 37. & $\begin{array}{l}\text { Explain transparency, accountability, probity } \\
\text { due process in relation to rule of law, fairness } \\
\text { and impartiality }\end{array}$ & 3.85 & 3.00 & 0.85 & IN \\
\hline 38. & $\begin{array}{l}\text { Post entries into different ledgers accounts } \\
\text { i.e. nominal, personal and impersonal } \\
\text { accounts }\end{array}$ & 3.76 & 3.64 & 0.12 & IN \\
\hline 39. & Balance ledger accounts & 3.96 & 3.56 & 0.40 & IN \\
\hline \multirow[t]{2}{*}{40.} & $\begin{array}{l}\text { Prepare income statements such as trading } \\
\text { accounts, profits and loss accounts and } \\
\text { balance sheet }\end{array}$ & 3.94 & 3.12 & 0.82 & IN \\
\hline & $\begin{array}{ll}\text { INFORMATION } & \text { COMMUNICATION } \\
\text { TECHNOLOGY } & \\
\end{array}$ & & & & \\
\hline 41. & Use input and output devices of computing & 3.92 & 3.58 & 0.34 & IN \\
\hline 42. & $\begin{array}{l}\text { Use computer to produce memo from given } \\
\text { manuscript }\end{array}$ & 3.74 & 3.53 & 0.23 & IN \\
\hline 43. & $\begin{array}{l}\text { Use computer to produce different types of } \\
\text { letter from given manuscript }\end{array}$ & 3.73 & 3.63 & 0.10 & IN \\
\hline
\end{tabular}


DEVELOPMENT

Vol. 1, No. 4, 2012, E-ISSN: $2226-6348$ @ 2012 HRMARS

\begin{tabular}{|l|l|l|l|l|l|}
\hline 44. & $\begin{array}{l}\text { Use the internet for communication and } \\
\text { information dissemination }\end{array}$ & 3.88 & 3.48 & 0.40 & IN \\
\hline 45. & Maintain data bank on business contact & 3.82 & 3.73 & 0.90 & IN \\
\hline
\end{tabular}

Table 3 reveals that performance gap values of the respondents in 14 task clustered items four task items in commerce, five in bookkeeping and five in ICT had positive values which range from 0.09 to 0.88 . This indicates that the teachers required improvement in all the task items except one which has a negative performance gap value of -0.04 which indicates that the teachers had no need for improvement in distinguishing between various forms of business organization.

\section{Discussion of Findings}

The findings of this study reveals that teachers of Business Studies in Ondo State public Junior secondary schools need improvement in instructional planning, implementation and evaluation skills, as well as in core Business skills in relation to the teaching of office practice, shorthand and keyboarding as well as in commerce, bookkeeping and ICT. The findings is corroborates Udoh, (1995), who carried out a study on the professional competencies needed by secondary schools Home Economics teachers in Edo State and found out that Home Economics teachers in Edo State needed improvement training in instructional planning, implementation and evaluation. This finding is supported also by Ingersoil, Gladam and Nwadiani cited in Udoh (1995) who found that teachers needed improvement training in adequate knowledge of evaluation techniques, selection of suitable teaching contents for lessons, as well as stimulating students' interest in learning in Edo State. In addition, this finding is supported by Olaitan, Amusa and Nwobu (2009) who found that instructors in teaching of cocoyam to students of Agriculture in South Western States of Nigeria needed improvement training in technical areas in cocoyam production such as planting, harvesting and marketing. This finding also corroborates the opinion of ILO (2010) that the dynamic of the Business environment require constant update of skills of Vocational and Technical Educators and trainers.

\section{Conclusion and Recommendations}

The findings of this study revealed that teachers of Business Studies in Ondo State public junior secondary schools need improvement training in instructional skills to effectively plan instruction, implement and evaluate teaching/ learning achievement in Business Studies at junior secondary school. The study equally reveals that these teachers had challenges in teaching business activities in relation to the components parts of business studies which are: shorthand, keyboarding, office practice, bookkeeping, commerce and ICT.

In the light of the findings of this study, this researcher recommends as follows:

1. that the identified tasks items where the teachers of Business Studies needed improvement be packaged for retraining of the in-service teachers of Business Studies in Ondo State junior secondary schools;

2. that Ondo State Government should organize seminars and workshops for teachers of Business Studies in the areas of identified needed tasks for improvement; and 
3. Colleges of education, National Teachers' Institute, Open University and universities in Nigeria should review their curriculum in line with identified tasks in which teachers of business studies needed improvement.

\section{References}

Adeniyi, E. O. (2007). Federal Ministry of Education 9-Year Basic Education Curriculum Business Studies for Junior Secondary 1-3, Nigerian Educational Research and Development Council: Abuja

Awoyokun, A. A., Akangbe-Folaranmi, A. O., Arukwe O. N., \& Abdullahi, I. M. (2009) Macmillan Business Studies UBE Edition, Macmillan Nigeria Ltd, Lagos.

Ehiametalor, E. T., Osu-Nwifo, K. O., Makeri-Yahaya, G. I., \& Oladunjoye. (2009). Junior Secondary School Business Studies 1, West African Book Publisher Ltd: Lagos.

Federal Government of Nigeria. (2004). National Policy on Education. Nigerian Educational Research and Development Council: Abuja.

Federal Ministry of Education. (2007). 9-Year basic education curriculum business studies for junior secondary 1-3. Nigerian Educational Research and Development Council: Abuja.

Filani, E. O. (2010). Teacher education in a democratized Nigeria: challenges and way forward. Being a Lead Paper Presented at the National Conference of South-West Colleges of Education Academic Staff Union (COEASU), Ondo.

Hornby, A. S. (2005). Advanced Learner's Dictionary Oxford Press.

International Labour Organization. (2010). Teachers and trainers for the future: technical and vocational education and training in a changing world: Report on Discussion at the Global Dialogue Forum on VTE.

Nworgu, B. G. (2000). Educational research: basic issues and methodology, wisdom. Ibadan: Publishers Limited

Olaitan, S. O., Ali, A., Eyo, E. O., \& Sowande. (2000). Research Skills in Education and Social Science, Owerri: Cape Publisher.

Olaitain, S. O., Amusa, T. A., \& Nwobu, V. (2009). Quality assurance of instructors in teaching cocoyam production to students in schools of agriculture in Southern Nigeria: Nigerian Vocational Journal Vol. 15(3).

Nwaodo, S. A. (2009). Workshop management competencies improvement needs of auto mechanics teachers in South Eastern States of Nigeria. Vocational Journal Vol. 14(1)

Eze, U. N., \& Agbomma, V. U. (2009). Relationship between science teachers' perceived self efficacy and job perception. Nigeria Vocational Journal Vol. 14(1). 